\title{
Correlation Between Oxidant and Antioxidant Status (MDA and SOD Expression) and the Improvement of Outer Hair Cells Function Due to Curcumin Administration in Noise-Exposed Rattus Norvegicus Cochlea Assessed by DPOAE Examination
}

\author{
Tengku Siti Hajar HARYUNA ${ }^{*}$, Reastuty REASTUTY ${ }^{1}$, Tengku Siti Harilza ZUBAIDAH², \\ Delfitri MUNIR ${ }^{1}$, Wibi RIAWAN ${ }^{3}$, Juliandi HARAHAP ${ }^{4}$ \\ 1 Department of Otorhinolaryngology, Faculty of medicine, Universitas Sumatera Utara, Medan, Sumatera Utara, 20155, \\ Indonesia \\ 2 Department of Ophtalmology, Faculty of medicine, Universitas Sumatera Utara, Medan, Sumatera Utara, 20155, Indonesia \\ 3 Department of Biochemistry and Molecular Biology, Faculty of medicine, Brawijaya University, Malang, East Java, 65145, \\ Indonesia \\ 4 Department of Community Medicine, Faculty of medicine, Universitas Sumatera Utara, Medan, Sumatera Utara, 20155, \\ Indonesia
}

\begin{abstract}
\footnotetext{
* Corresponding author:

Address: Department of Otorhinolaryngology, Faculty of medicine, Universitas Sumatera

Utara, 5 dr. Mansur street, Medan, Sumatera Utara, Indonesia. 20155

email: tengkusitihajarharyuna@gmail.com / tengkusitihajarharyuna@usu.ac.id

Mobile : +62812606194

ORCID Number :

Tengku Siti Hajar Haryuna : :0000-0003-2779-3285

Reastuty : :0000-0003-4608-8629

Tengku Siti Harilza Zubaidah : 0000-0002-9433-0873

Delfitri Munir : :0000-0002-8526-6398

Wibi Riawan : :0000-0001-5027-5051

Juliandi Harahap : : :0000-0002-1090-2003

(Received 07 Oct 2020, Accepted 29 Mar 2021)
}

NIHL caused by excessive noise exposed to cochlea. Curcumin is a medicine that has antioxidant effects. The purpose of this study was to look at the effect of curcumin on NIHL which was assessed with DPOAE, value and the expression of SOD and MDA. This research was conducted on 36 rats which were divided into 6 groups, group 1 was a control group, group 2 was a group receiving only noise treatment, groups 3 and 4 were the treatment group receiving curcumin after exposed to noise, groups 5 and 6 were preventive groups receiving curcumin starting from 14 
days before their get noise. The study result showed the correlation between SOD and MDA expression and DPOAE value due to curcumin Administration in NoiseExposed rats Cochlea. The conclussion of the study showed that curcumin was able to change the value of DPOAE, SOD and MDA expressions in rats exposed to noise.

Key words : Curcumin, noise, cochlea, antioxidants, superoxide dismutase

\section{INTRODUCTION}

Nowadays there is a lot of noise at work that causes workers to suffer from hearing loss due to work. Besides environmental noise also increased, this resulted in around 1-1.6 million people in western Europe or 1.1 million world population suffer from Noise Induced Hearing Loss (NIHL) every year. The UN World Health Organization estimates that 1.1 billion people in the world are at risk of suffering from NIHL because of the fallacy in listening behavior. In high and middle income countries, adolescents and young adults aged 1235 years are exposed to excessive sound through personal audio devices and around $40 \%$ of them occur in clubs, discos and bars ${ }^{1}$.

Noise will cause a shearing force that results in changes in the stereocilia of hair cells outside the cochlear basilar membrane and cell death will occur if the process occurs excessively ${ }^{2}$. Studies in animals exposed to noise showed anatomic changes occur ranging from stereocilia distortion of outer and inner hair cells to loss of cortical organs and rupture of the Reissner membrane. In general, changes in blood vessels, spirals or limb ligaments are not found. Stria vascular edema occurs a few minutes after exposure to noise and persists for several days ${ }^{3}$. Noise can cause Temporary Treshold Shift (TTS) or Permanent Threshold Shift (PTS). Generally, in TTS, the hearing will return to normal within 2448 hours $^{4}$. The cause of cortical organ damage can occur in two mechanisms, namely mechanical damage and continuous metabolic activity ${ }^{1}$.

Many studies carried out over nearly 40 years have shown that otoaccoustic emission (OAE) is useful for determining the differential diagnosis of sensorineural hearing loss; cochlear screening of infants, toddlers and other patients that are difficult for hearing tests; assess outer hair cells in patients exposed to excessive noise, ototoxic or other progressive disease sufferers ${ }^{5}$. One type of OAE examination is Distortion Product Otoacoustic Emission (DPOAE), this examination is very suitable and sensitive to assess ear responses to dangerous stimuli such as toxic, trauma and cochlear degenerative processes ${ }^{6}$.

Oxidative stress due to noise exposure damages the antioxidant defense mechanism in the cochlea so that Reactive Oxygen species (ROS), Reactive Nitrogen Species (RNS) and other free radicals are formed excessively, to overcome this 
detoxification process occurs. This defense mechanism consists of enzymes and antioxidants. Enzymes such as Superoxide Dismutase (SOD) catalyze the removal of $\mathrm{O}_{2}$ - to $\mathrm{H}_{2} \mathrm{O}_{2}$, Glutathione peroxidase (GPx), Glutathione reductase (GR) and Catalase (CAT) 7 . Oxygen free radicals can attack proteins, nucleic acids and lipid membranes that disrupt the normal function and integrity of cells. An increase in neurotransmitters in the brain area after exposure to noise and can persist for up to 15 days after exposure. In addition there is also an increase in Malondialdehyde (MDA) as the end result of lipid peroxidation ${ }^{8}$ and is a marker for damage caused by free radicals9.

In the future prevention and treatment efforts for NIHL can be increased by the use of chemoprotective agents such as antioxidants and identification of risk factors ${ }^{2}$. Turmeric (Curcuma longa Linn) is one of the most well-known herbal medicines and has many pharmacological activities such as antioxidants, antiinflammation, anti-tumor, anti-proliferation, anti-angiogenic, anti-aging, antiprotozoa, anti-microbial, and anti-malaria ${ }^{10}$. Turmeric has the main active components namely curcuminoids, monoterpenoids and sesquiterpenoids ${ }^{11}$. Whereas curcuminoids, consisting of curcumin, demethoxycurcumin and bisdemethoxycurcumin ${ }^{10,11}$.

Previous studies have shown that curcumin has the effect of preventing and treating the damage of supporting fibroblast cells and the lateral wall of the cochlea due to noise exposure with increased SOD and CAT expression ${ }^{12}$ and decreased MDA and $\mathrm{H}_{2} \mathrm{O}_{2}$ expression ${ }^{13}$.

This study is different from the previous studies, in this study we want to prove that curcumin is able to cause changes in oxidant and antioxidant status in hair cells / cochlear cortical organs so that the outer hair cell function improves as evidenced by DPOAE examination in rats exposed to noise.

\section{METHODOLOGY}

This study used a randomized post test only control group laboratory experimental design. This study founded by Research Institute of the Universitas Sumatera Utara under the TALENTA Research Implementation Contract of the Universitas Sumatera Utara 2018 fiscal year No: 2590 / UN.5.1.R / PPM / 2018 on March 16, 2018.

\section{Ethical Approval}

Before the study was conducted, this study approved ethical clearance from the ethics research institute of the Faculty of Medicine, Universitas Sumatera Utara with number 509 / TGL / KEPK FK USU-RSUP HAM / 2018. 


\section{The Groups of The Study}

The study was conducted on 36 male Rattus norvegicus pure strain rats, weighing 200-300 grams and declared healthy by veterinarians. All rats were treated in a polycarbonil cage to ensure the temperature of the cage remained at $20^{\circ} \mathrm{C}-$ $26^{\circ} \mathrm{C}$ with humidity around $30-70 \%$. It is ensured that all rat receive sufficient light sources and get adequate food and drink ${ }^{14}$.

This study was divided into 6 groups, each consisting of 6 rats. The first group is a control group without administration of curcumin and noise exposure. Group 2 is a group of rats with only noise exposure without curcumin. Group 3 and group 4 are curative groups. Group 3 is a group with noise exposure and curcumin $100 \mathrm{mg}$ / day for 2 days after exposure to noise. Group 4 is a group with noise exposure and curcumin $200 \mathrm{mg}$ / day for 2 days after giving noise exposure. Group 5 is a preventive group that starts with $100 \mathrm{mg}$ of curcumin / day for 2 weeks followed by noise exposure and $100 \mathrm{mg}$ / day of curcumin for 2 days. Group 6 is a preventive group that starts with $200 \mathrm{mg}$ / day of curcumin for 2 weeks followed by noise recording given at a frequency of $1-10,000 \mathrm{~Hz}$ with an intensity of $110 \mathrm{~dB}$ for 2 hours / day, for 2 days. Noise treatment is carried out by placing rats on a box (with a size of $64.5 \mathrm{x}$ $45 \times 40$ ) $\mathrm{cm}$ made of cork coated by foam, speakers are placed attached to the roof of the box cover and a hole is made at the base of the box to measure the intensity, measurements are made at eight points where the cage will be placed with a noise difference not exceeding $1 \mathrm{~dB}$ using a sound level meter.

\section{Procedures of DPOAE examination.}

Examination of DPOAE using Distortion Product Otoacoustic Emissions (DPOAE) of the brand Elios Elito Otodia (Echodia Ltd., London, UK) was carried out 2 times; before the noise treatment was carried out and after 2 days of noise treatment. Before examination, rats were first anesthetized using Ketamine at a dose of $90 \mathrm{mg} / \mathrm{kgBW}$ and Xylazine at a dose of $10 \mathrm{mg} / \mathrm{kgBW}$ which was injected intraperitoneally ${ }^{15,16}$

\section{Procedures for Curcumin Administration}

In this study, curcumin given was extracted from Curcuma longa $L$ (turmeric, with certificate number 0532 / SA / V / 2016, certified by Dr. Rer. Nat. M. Yuwono, MS, Department of Pharmacy, Airlangga University) with a concentration of $16.62 \% \pm 0.14 \% \mathrm{w} / \mathrm{w}$ calculated by the TLC-densitometry method. Curcumin given at a dose of $100 \mathrm{mg}$ and $200 \mathrm{mg}$, which was diluted in CMC / Carboxy methyl cellulose 0.5\% was given using Nasogastric Tube (NGT). After all treatments were completed, the rats were terminated by inhalation of ether and necropsing of the rat's temporal bone. 


\section{Immunohistochemistry Staining}

Temporal bone taken was fixed with 10\% formalin buffer solution, then by using EDTA for 4 weeks it was expected for decalcification to occur. Next, each tissue sample was prepared in a paraffin block and sliced into $4 \mu \mathrm{m}$ thick sections and placed in a slide and then stained with hematoxylin-eosin and immunohistochemical staining. SOD staining with primary antibodies (SOD-2 (A-2) (Santa Cruz Biotechnology, Inc. cat \# sc-133134)) and MDA with antimalondialdehyde antibodies (abcam cat \# ab6463) to assess SOD and MDA expression in cortical organs cochlea. The XC 10 Olympus microscope using 4OX magnification was used to calculate SOD and MDA expressions using a double-blind method performed by two examiners separately (researcher and anatomist pathologist). SOD and MDA expressions were assessed by a broad score (P) and Intensity score (I) of the brown color on the cytoplasm. Intensity score: $1-3$, broad score 0: 0\%; 1: <10\%; 2: $11 \%-50 \% ; 3: 51-80 \% ; 4:>80 \%$ to obtain an immune-reactive score which is the product of $\mathrm{P}$ and I multiplication, with a value of $0-12^{17}$.

\section{Statistical Analyze}

All data collected was analyzed statistically using the ANNOVA test to assess differences in each treatment and bivariate analysis was also performed using the Pearson test to assess the correlation between DPOAE examination with SOD and MDA expressions.

\section{RESULT AND DISCUSSION}

To get the appropriate cut of the cochlea, hematoxylin-eosin staining is done before immunohistochemical staining. A picture of cochlea with hematoxylin eosin staining can be seen in Figure 1 below.

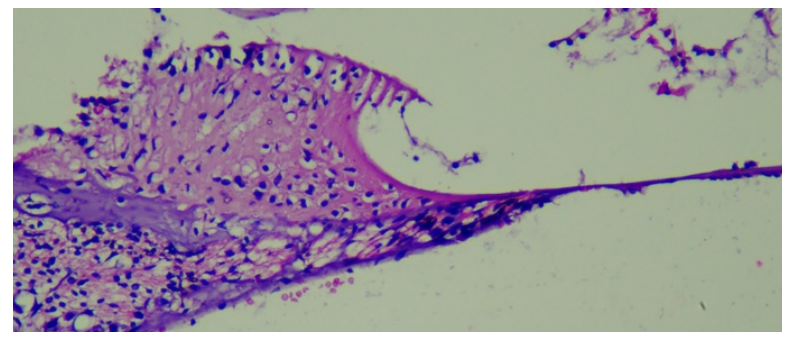

Figure 1: Figure of Rattus norvegicus (red arrow) cochlear cortical organ with hematoxylin-eosin staining under 400 magnification. 
The SNR value of group 2, the group that received only the lowest noise of 110 $\mathrm{dB}$ when compared with the control group (group 1) and the group receiving curcumin (groups $3,4,5$, and 6 ) as shown in table 1 . ANOVA test found significant differences between groups $(\mathrm{p}=0,000)$ as seen in table 2. Table 3 shows the significant differences between the control group (group 1) with the group that only gets noise treatment (group 2) and the group given curcumin (group 4,5 and 6) with a value of $\mathrm{p}<0.05$. In this study no significant differences were found in changes in SNR values between the preventive group and between the curative groups regarding the difference in curcumin doses of 100 and $200 \mathrm{mg}$.

Table 1. Average SNR scores between groups

\begin{tabular}{cccc}
\hline & N & Mean & Standard Deviation \\
\hline Group 1 & 6 & 9,833 & 2,2923 \\
Group 2 & 6 & 4,167 & 2,4147 \\
Group 3 & 6 & 7,767 & 1,1759 \\
Group 4 & 6 & 6,800 &, 6197 \\
Group 5 & 6 & 6,833 &, 9245 \\
Group 6 & 6 & 6,000 &, 4382 \\
\hline Total & 36 & 6,900 & 2,2386 \\
\hline
\end{tabular}

Table 2. ANOVA Test of SNR Value in Each Group

\begin{tabular}{ccc}
\hline Group & Mean Difference \pm Standard Deviation & p Value \\
\hline Group 1 & $9,833 \pm 2,2923$ &, $000^{*}$ \\
Group 2 & $4,167 \pm 2,4147$ & \\
Group 3 & $7,767 \pm 1,1759$ \\
Group 4 & $6,800 \pm 0,6197$ \\
Group 5 & $6,833 \pm 0,9245$ \\
\hline Group 6 & $6,000 \pm 0,4382$ \\
\hline
\end{tabular}

* Differences are statistically significant 
Table 3. Post Hoc Test Value SNR Value

\begin{tabular}{|c|c|c|c|}
\hline & & Mean difference & p Value \\
\hline \multirow[t]{5}{*}{ Group 1} & Group 2 & 5,6667 & $0,000^{*}$ \\
\hline & Group 3 & 2,0667 & 0,206 \\
\hline & Group 4 & 3,0333 & $0,019^{*}$ \\
\hline & Group 5 & 3,0000 & $0,021^{*}$ \\
\hline & Group 6 & 3,8333 & $0,002^{*}$ \\
\hline \multirow[t]{4}{*}{ Group 2} & Group 3 & $-3,6000$ & $0,004^{*}$ \\
\hline & Group 4 & $-2,6333$ & 0,055 \\
\hline & Group 5 & $-2,6667$ & 0,051 \\
\hline & Group 6 & $-1,8333$ & 0,321 \\
\hline \multirow[t]{3}{*}{ Group 3} & Group 4 & 0,9667 & 0,877 \\
\hline & Group 5 & 0,9333 & 0,892 \\
\hline & Group 6 & 1,7667 & 0,360 \\
\hline \multirow[t]{2}{*}{ Group 4} & Group 5 & $-0,0333$ & 1,000 \\
\hline & Group 6 & 0,8000 & 0,941 \\
\hline Group 5 & Group 6 & 0,8333 & 0,930 \\
\hline
\end{tabular}

\section{*Differences are statistically significant}

SOD expression decreased in the group that only received noise treatment (group 2) when compared to the control group (group 1) and increased in the group with noise treatment and curcumin administration (groups 3,4,5, and 6) seen in table 4. In the figure 2 the brown color shows SOD expression where there is a decrease in the intensity of brown color in the cytoplasm of cochlear cortical organs of group 2 compared to the control group and seen an increase in the intensity of brown color in group 3,4,5, and 6 when compared to group 2. As seen in Table 5 in this study was found significant differences between groups. Table 6 shows that in this study there were significant differences between the groups that only received noise treatment, namely group 2 and all groups. In the group that given curcumin, the difference in curcumin dose in the curative group (groups 3 and 4) and the preventive group (groups 5 and 6) did not have a significant difference with a p value of $<0.05$. 

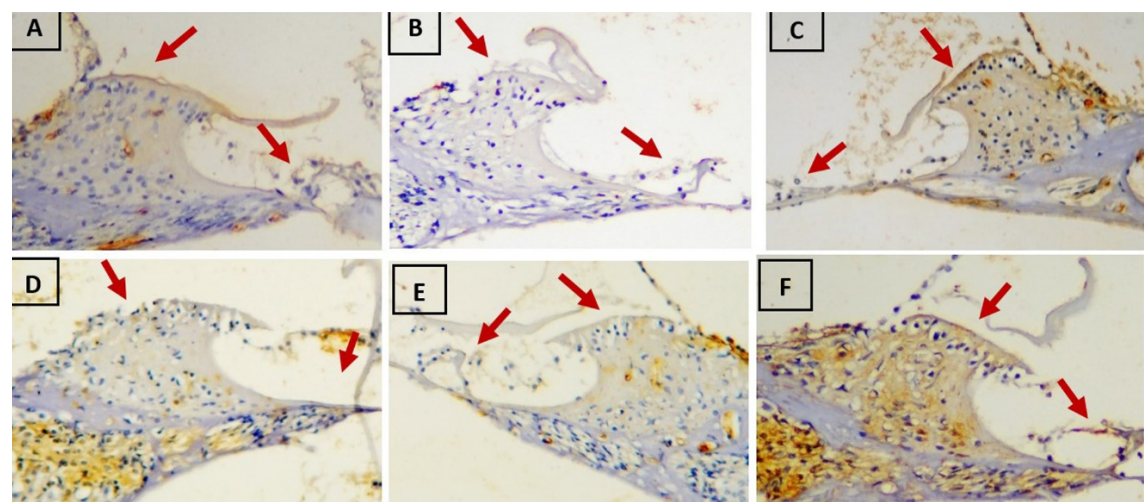

Figure 2: SOD expression in each group under 400 magnification, namely A; Group 1, B; Groups 2 and C; Group 3, D; group 4, E; group 5 and F; group 6, arrows show SOD expression in cochlear cortical organs which are marked in brown.

Table 4. Average SOD Expressions for each group

\begin{tabular}{cccc}
\hline & N & Mean & Standard Deviation \\
\hline Group 1 & 6 & 9,00 & 1,897 \\
\hline Group 2 & 6 & 4,00 & 1,897 \\
\hline Group 3 & 6 & 8,17 & 2,563 \\
\hline Group 4 & 6 & 9,83 & 2,563 \\
\hline Group 5 & 6 & 8,50 & 1,975 \\
\hline Group 6 & 6 & 10,00 & 2,449 \\
\hline Total & 36 & 8,25 & 2,912 \\
\hline
\end{tabular}

Table 5. ANOVA Test on SOD Expression in Each Group

\begin{tabular}{ccc}
\hline Group & Mean Difference \pm Standard Deviasi & p Value \\
\hline Group 1 & $9,00 \pm 1,897$ &, $001^{*}$ \\
\hline Group 2 & $4,00 \pm 1,897$ & \\
\hline Group 3 & $8,17 \pm 2,563$ & \\
\hline Group 4 & $9,83 \pm 2,563$ \\
\hline Group 5 & $8,50 \pm 1,975$ \\
\hline Group 6 & $10,00 \pm 2,449$ \\
\hline
\end{tabular}

* Differences are statistically significant 
Table 6. Post Hoc Test for SOD Expression

\begin{tabular}{cccc}
\hline & & Mean Differnce & p Value \\
\hline \multirow{2}{*}{ Group 1 } & Group 2 & 5,000 & $0,007^{*}$ \\
\cline { 2 - 4 } & Group 3 & 0,833 & 0,987 \\
\cline { 2 - 4 } & Group 4 & $-0,833$ & 0,987 \\
\hline \multirow{2}{*}{ Group 2 } & Group 5 & 0,500 & 0,999 \\
\hline & Group 6 & $-1,000$ & 0,970 \\
\hline & Group 3 & $-4,167^{*}$ & $0,033^{*}$ \\
\hline & Group 4 & $-5,833^{*}$ & $0,001^{*}$ \\
\hline \multirow{2}{*}{ Group 3 } & Group 5 & $-4,500^{*}$ & $0,018^{*}$ \\
\hline & Group 6 & $-6,000^{*}$ & $0,001^{*}$ \\
\hline & Group 4 & $-1,667$ & 0,790 \\
\hline \multirow{2}{*}{ Group 4 } & Group 5 & $-0,333$ & 1,000 \\
\hline & Group 6 & $-1,833$ & 0,718 \\
\hline Group 5 & Group 5 & 1,333 & 0,904 \\
\hline & Group 6 & $-0,167$ & 1,000 \\
\hline & Group 6 & $-1,500$ & 0,853 \\
\hline
\end{tabular}

* Differences are statistically significant.

Figure 3 shows an increase in the intensity of the brown color in the cytoplasm of the cochlear cortical organ which shows increased expression of MDA in group 2 compared to the control group. In groups 3,4,5 and 6 there was a decrease in the intensity of the brown color in the cytoplasm of the cochlear cortical organ when compared to group 2. As shown in table 7 , this study found an increase in MDA expression in the group that received only noise treatment (group 2) when compared with the control group (group 1), and found a decrease in MDA expression in the group with the administration of noise and curcumin (groups $3,4,5$ and 6) but not lower or equal to the value of MDA expression in group 1. With the ANOVA test was found a significant difference between groups as seen in table 8. In this study was found significant differences in the expression of MDA in the group that only received noise treatment (group 2) with all groups both the control group (group 1) as well as the noise and curcumin administration group (group 3,4 ,5, and 6) as shown in table 9. Differences in dose did not show significant differences either in the curative group and preventive groups. 

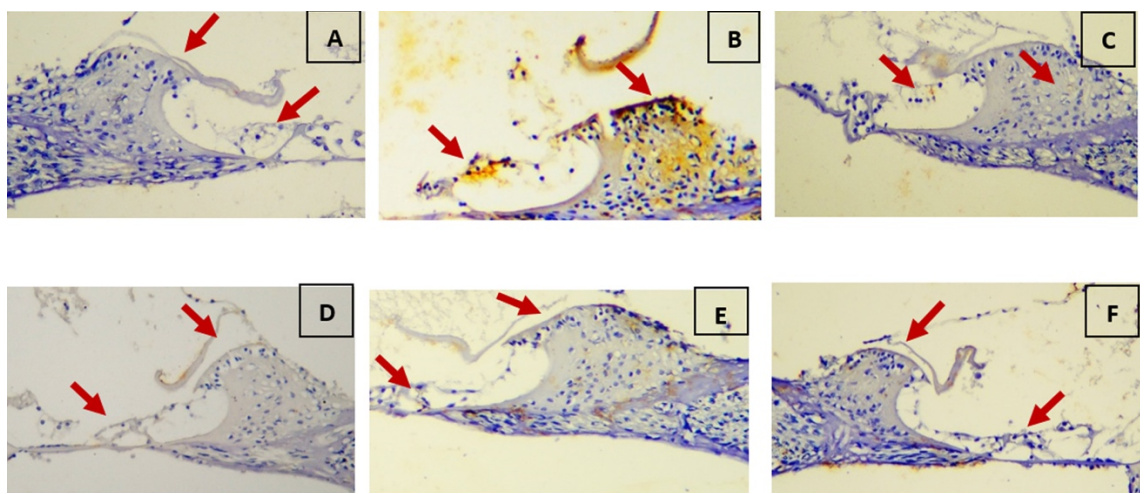

Figure 3: MDA Expressions in each group under 400 magnification, namely A; Group 1, B; Groups 2 and C; Group 3, D; group 4, E; group 5 and F; group 6, arrows show MDA expression in cochlear cortical organs which are marked in brown.

Table 7. The mean values of MDA expressions for each group

\begin{tabular}{cccc}
\hline & N & Mean & Standard Deviation \\
\hline Group 1 & 6 & 2,00 & 1,095 \\
\hline Group 2 & 6 & 7,33 & 3,670 \\
\hline Group 3 & 6 & 3,33 & 1,751 \\
\hline Group 4 & 6 & 3,17 & 1,941 \\
\hline Group 5 & 6 & 3,33 & 1,966 \\
\hline Group 6 & 6 & 3,17 & 2,317 \\
\hline Total & 36 & 3,72 & 2,700 \\
\hline
\end{tabular}

Table 8. ANOVA Test of MDA Expressions in Each Group

\begin{tabular}{ccc}
\hline Group & Mean Difference \pm Standard Deviation & p Value \\
\hline Group 1 & $2,00 \pm 1,095$ &, $007^{\star}$ \\
Group 2 & $7,33 \pm 3,670$ & \\
Group 3 & $3,33 \pm 1,751$ & \\
Group 4 & $3,17 \pm 1,941$ & \\
Group 5 & $3,33 \pm 1,966$ & \\
Group 6 & $3,17 \pm 2,317$ & \\
\hline
\end{tabular}

* Differences are statistically significant 
Table 9. Post Hoc Test MDA expression values

$\begin{array}{cccc} & & \text { Mean Difference } & \text { p Value } \\ \text { Group 1 } & \text { Group 2 } & -5,333 & 0,004^{*} \\ & \text { Group 3 } & -1,333 & 0,907 \\ & \text { Group 4 } & -1,167 & 0,945 \\ & \text { Group 5 } & -1,333 & 0,907 \\ & \text { Group 6 } & -1,167 & 0,945 \\ \text { Group 2 } & \text { Group 3 } & 4,000 & 0,048^{*} \\ & \text { Group 4 } & 4,167 & 0,036^{\star} \\ \text { Group 3 } & \text { Group 5 } & 4,000 & 0,048^{*} \\ & \text { Group 6 } & 4,167 & 0,036^{*} \\ \text { Group 4 } & \text { Group 4 } & 0,167 & 1,000 \\ \text { Group 5 } & \text { Group 5 } & 0,000 & 1,000 \\ & \text { Group 6 } & 0,167 & 1,000 \\ & \text { Group 5 } & -0,167 & 1,000 \\ & \text { Group 6 } & 0,000 & 1,000 \\ & \text { Group 6 } & -0,167 & 1,000\end{array}$

* Differences are statistically significant

All SNR values of SOD and MDA expression in each group are normally distributed so that the Pearson test can be performed on all groups. Pearson test results show there is a siginificant positive correlation between the value of SNR with SOD expression and siginificant negative correlation between the value of SNR with MDA expression in groups 2, 3, 4, 5, and 6 as shown in table 10. 
Table 10. Person Correlation betweem SNR values with SOD expressions and MDA expressions of the Groups

\begin{tabular}{|c|c|c|c|c|}
\hline Group & & Mean \pm Standard Deviation & $\mathbf{R}$ & p Value \\
\hline \multirow{3}{*}{ Group 2} & SOD & $4,00 \pm 1,897$ & 0,891 & $0,17^{\star}$ \\
\hline & MDA & $7,33 \pm 3,670$ & $-0,816$ & $0,48^{*}$ \\
\hline & SNR & $4,167 \pm 2,4147$ & & \\
\hline \multirow{3}{*}{ Group 3} & SOD & $8,17 \pm 2,563$ & 0,905 & $0,13^{\star}$ \\
\hline & MDA & $3,33 \pm 1,751$ & $-0,907$ & $0,13^{*}$ \\
\hline & SNR & $7,767 \pm 1,1759$ & & \\
\hline \multirow{3}{*}{ Group 4} & SOD & $9,83 \pm 2,563$ & 0,831 & $0,040^{*}$ \\
\hline & MDA & $3,17 \pm 1,941$ & $-0,865$ & $0,026^{*}$ \\
\hline & SNR & $6,800 \pm 0,6197$ & & \\
\hline \multirow{3}{*}{ Group 5} & SOD & $8,50 \pm 1,975$ & 0,822 & $0,045^{\star}$ \\
\hline & MDA & $3,33 \pm 1,966$ & $-0,887$ & $0,018^{*}$ \\
\hline & SNR & $6,833 \pm 0,9245$ & & \\
\hline \multirow{3}{*}{ Group 6} & SOD & $10,00 \pm 2,449$ & 0,894 & $0,016^{*}$ \\
\hline & MDA & $3,17 \pm 2,317$ & $-0,867$ & $0,025^{*}$ \\
\hline & SNR & $6,000 \pm 0,4382$ & & \\
\hline
\end{tabular}

\section{* Statistically significant}

Noise exposure causes a variety of damage to the cochlea both during noise exposure and after the noise exposure is stopped so that it will ultimately affect hearing sensitivity ${ }^{18}$. Regular or prolonged exposure to noise can cause damage to the sensory cells and other structures gradually, which cannot be recovered, leading to PTS (Permanent Threshold Shift) ${ }^{1}$. Noise can cause damage to cochlear function through 7 mechanisms, namely free radical formation, mechanical damage, release of glutamate into hair cells in the cochlea, excessive stimulation of $\mathrm{N}$ methyl-D-aspartame receptors that cause nitric oxide release, decrease in magnesium which causes changes in intracellular activity, increased intracellular calcium activity and protein damage $\mathrm{e}^{19}$.

The formation of free radicals will cause oxidative stress. Antioxidants in general function as free radical scavenger which can repair damage caused by free radicals. Curcumin is known as an antioxidant and is reported to have free radical scavenger activity ${ }^{20}$. Other studies have concluded that administration of curcumin before and during paclitaxel can significantly protect the morphology and function of cochlea in pacoxitaxel-induced ototoxic rats assessed by using a light microscope and DPOAE examination to evaluate histopathology, immunohistochemistry, and hearing functional changes ${ }^{21}$.

In this study group 2 that received noise treatment for 2 days with an intensity 
of $110 \mathrm{~dB}$ for 2 hours the SNR value decreased compared to the control group, this shows that in group 2 there was NIHL. In groups 3, 4, 5, and 6 which are groups with the same noise treatment group as group 2 followed by administration of curcumin there was an increase in SNR value $\geq 6$. In this study also found a significant difference in SNR values between group 1 and group 2, 4, 5 and 6 ( $\mathrm{p}<0.05$ ) which can be interpreted that the administration of curcumin in the group with the noise treatment can increase the SNR value, this is in accordance with previous studies conducted by Yamaguchi et al who found that the administration of curcumin orally for 3 days before and each days during noise exposure significantly reduce hearing loss caused by repeated noise exposure. In that study the auditory hearing used was BERA and was found that dose of $100 \mathrm{mg} / \mathrm{kgBW}$ of curcumin was capable of partially but significantly attenuating the noise-induced elevation of the auditory threshold at 12 and 20 $\mathrm{KHz}$ frequencies ${ }^{22}$.

SOD expression decreased in the noise treatment group only (group 2) when compared to the control group (group 1) and increased in the group with noise treatment and curcumin administration (groups 3,4,5, and 6). Significant differences were found between the groups that were only exposed to noise (Group 2) with the control group and the group that received noise exposure followed by the administration of curcumin (groups $3,4,5$, and 6) ( $<<0.05$ ). This study is in accordance with research conducted by Kavakli et al who found that administration of curcumin protected spinal cord tissue from oxidative damage through a mechanism of increasing SOD enzyme activity and a decrease in MDA levels in rat animals which were subjected to spinal cord trauma and laminectomy ${ }^{23}$. Curcumin can increase the antioxidant status and expression of caspase-9 gene and inhibit the process of oxidative stress and lipid peroxidation in rat colon cancer tissue induced by 1,2-dimethylhydrazine. Curcumin has been shown to increase SOD and GST activity and levels of GSH, caspase-9 and DNA fragmentation and reduce the increase in MDA and NO concentrations that occur in the colon tissue ${ }^{24}$. This study is also in accordance with the research conducted by Meshkibav et al who found that curcumin increases the level of antioxidant enzymes such as SOD, CAT and GPx in rats with arthritis models. The study also found that the increase in MRSA levels was due to the antioxidant effect of curcumin ${ }^{25}$.

This study found an increase in MDA expression in the group that received only noise treatment (group 2) when compared to the control group (group 1). This is in accordance with the research by Demirel et al which showed an increase in MDA levels, indicators of lipid peroxidation, as well as NO levels 
and GSH-Px activity by noise exposure indicating oxidative stress which can cause various levels of damage in cells, especially through lipid peroxidation pathways $^{8}$. In the group with noise treatment followed by administration of curcumin of group 3, 4, 5, and 6 was found a decrease in the value of MDA and found significant differences between the group that only received treatment (group 2 compared) to all groups that received noise treatment followed by administration of curcumin (groups 3,4,5, and 6). Research conducted by Zheng et al (2009) found that administration of curcumin was able to reduce MDA levels and expression of c-fos protein in the brains of rats that were damaged due to ischemic hypoxia. In this study an improvement was seen in changes in the structure and morphology of neuron cells in the cortex of the rat brain after administration of curcumin ${ }^{26}$.

In the previous study, curcumin was found to be able to significantly increase SOD expression ${ }^{11}$ and decrease MDA expression ${ }^{12}$ in noise-exposed cochlear fibroblasts ( $\mathrm{p}<0.05$ ). However, this study proves that curcumin can increase SOD expression and decrease MDA expression in outer cochlear hair cells in rats that are exposed to noise, causing improvement in outer hair cell function as measured by the increase of SNR values on DPOAE examination. Was also found a positive correlation between SNR values with SOD expression and negative correlations between SNR values with MDA expression in all treatment groups. Increased SOD expression and decreased MDA values led to an increase in the SNR value after administration of curcumin in groups 3,4,5, and 6. In the end this study, the results could perform as the basis of benchmarks for further studies in humans that prove the benefits of curcumin in repairing cochlear cortical organ damage which is assessed by DPOAE examination. Research by Soyalıç et al found that curcumin can protect cochlear tissue from acoustic trauma in rat. Intra-peritonial curcumin injection before and after acoustic trauma reduces cochlear hair cell damage and protects from hearing damage assessed by DPOAE, histopathological and immunohistochemical examinations ${ }^{27}$.

This research proves the existence of Correlation between Oxidant (MDA) and Antioxidant (SOD) Status and the improvement of outer hair cell function which is assessed by DPOAE examination in the cochlea of Rattus norvegicus which is exposed to noise due to curcumin administration, where positive correlation was found between SOD expression and SNR value and negative correlation between MDA expression and SNR value. 


\section{ACKNOWLEDGEMENTS}

The authors would thank the Research Institute of the Universitas Sumatera Utara for funding support under the TALENTA Research Implementation Contract of the University of North Sumatra 2018 fiscal year No: 2590 / UN.5.1.R / PPM / 2018 on March 16, 2018.

\section{FUNDING SOURCES}

This work was supported by Research Institute of the Universitas Sumatera Utara under the TALENTA Research Implementation Contract of the Universitas Sumatera Utara 2018 fiscal year No: 2590 / UN.5.1.R / PPM / 2018 on March 16, 2018.

\section{CONFLICT OF INTEREST}

Nothing to declare

\section{AUTHOR CONTRIBUTION}

Design: Tengku Siti Hajar Haryuna

Acquisition of data: Reastuty

Analysis of data: Tengku Siti Hajar Haryuna and Reastuty (these authors contributed equally)

Drafting of the manuscript: Tengku Siti Hajar Haryuna and Reastuty (these authors contributed equally)

Critical revision of the manuscript: Tengku Siti Hajar Haryuna and Delfitri Munir (these authors contributed equally)

Statistically analisis: Tengku Siti Hajar Haryuna, Reastuty and Juliandi Harahap (these authors contributed equally)

Technical and Financial Support: Tengku Siti Hajar Haryuna, Tengku Siti Harilza Zubaidah and Delfitri Munir (these authors contributed equally)

Supervision: Tengku Siti Hajar Haryuna (this author contibuted fully)

Other (Specify): Histopatological and molecular biology expertise: Wibi Riawan 


\section{REFERENCES}

1. World Health Organization. Hearing loss due to recreational exposure to loud sounds: a review. World Health Organization. 2015 https://apps.who.int/iris/handle/10665/154589

2. Rabinowitz ME, Noise-induced hearing loss. Am Fam Physician, 2000; 61(9):2749-56

3. Mathur NN, Noise induced hearing loss. emedicine 2020 July 13 https://emedicine.medscape.com/article/857813-overview

4. Le NT, Straatman VL, Lea J, Westerberg B. Current insights in noise-induced hearing loss: a literature review of the underlying mechanism, pathophysiology, asymmetry, and management options. J Otolaryngol Head Neck Surg, 2017;46(1):1-15. https://doi.org/10.1186/s40463017-0219-x.

5. Martin LLB, Martin GK, Otoacoustic emissions disorders of peripheral and central auditory processing. Handbook of Clinical Neurophysiology. 2013; 10(6):115-34

6. Saurini P, Nola G, Lendvai D, Otoacoustic emissions: a new method for newborn hearing screening. Eur Rev Med Pharmaco Sci. 2004;8(3):129-133

7. Choi $\mathrm{CH}$, Mechanisms of noise-induced hearing loss and treatment. Audiol. 2011;7:124-32. http://doi.org/10.21848/audiol.2011.7.2.124

8. Demirel R, Mollaoğlu H, Yeşilyurt H, Üçok K, Ayçiçek A, Akkaya M,et al. Noise induces oxidative stress in rat. Eur J Gen Med. 2004;6(1):20-24

9. Özgüner MF, Delibaş N, Tahan V, Koyu A, Köylü H, Effects of industrial noise on the blood levels of superoxide dismutase, glutathione peroxidase and malondialdehyde. Eastern Jour Med. 1999;4(1):13-15

10. Amalraj A, Pius A, Gopi S, Gopi S, Biological activities of curcuminoids, other biomolecules from turmeric and their derivatives A review. J Tradit Complement Med. 2016;7(2):205-33. https://doi.org/10.1016/j.jtcme.2016.05.005

11. Hadi S, Artanti AN, Rinanto Y, Wahyuni DSC, Curcuminoid content of Curcuma longa L. and curcuma xanthorrhiza rhizome based on drying method with NMR and HPLC-UVD. Mater. Sci. Eng. 2018;349. https://doi.org/10.1088/1757-899X/349/1/012058

12. Haryuna TSH, Riawan W, Reza M, Saragih AR, Modulation of antioxidant status by curcumin prevents cochlear damage after noise exposure. J. Chem. Pharm. Res. 2015;7(11)593-7

13. Haryuna, TSH, Riawan W, Reza M, Purnami N, Adnan A, Curcumin prevents cochlear oxidative damage after noise exposure. Int J Pharm Pharm Sci. 2016;8(1):175-8

14. National Research Council (US) Committee for the Update of the Guide for the Care and Use of Laboratory Animals. Guide for the Care and Use of Laboratory Animals. 8th ed. Washington (DC): National Academies Press (US). 2011:1-220

15. Albert Einstein College of Medicine. Recommended Methods of Anesthesia, Analgesia, and Euthanasia for Laboratory Animal Species. Institute for Animal Studies Veterinarians. 2014. https://www.spandidos-publications.com/var/RecommendedMethodsAnesthesiaAnalgesiaEuthanasia.pdf

16. Toydemir T, Kanter M, Erboga M, Oguz S, Erenoglu C, Antioxidative, antiapoptotic and proliferative effect of curcumin on liver regeneration after partial hepatectomy in rats. Toxicol Ind Health. 2015;31(2):162-72. https://doi.org/10.1177/0748233712469658 
17. Czogalla B, Kahaly M, Mayr D, Schmoekel E, Niesler B, Kolben T, et al. Interaction of ERa and NRF2 impacts Survival in Ovarian Cancer Patients. Inj J Mol Sci. 2018;20(1):112. https:// doi.org/10.3390/ijms20010112

18. Hu BH, Henderson D, Nicotera MT, Involvement of apoptosis in progression of cochlear lesion following exposure to intense noise. Hear Res. 2002;16(1-2):62-71. https://doi. org/10.1016/so378-5955(02)oo286-1

19. Alcarás PAS, Lüders D, França DMVR, Klas RM, lacerda ABML, Gonçalves CGO, Evoked otoacoustic emissions in workers exposed to noise: a review. Int Arch Otorhinolaryngol. 2012; 16(4):515-22. https://doi.org/10.7162/S1809-97772012000400014

20. Choudhury AK, Raja S, Mahapatra S, Nagabhushanam K, Majeed M, Synthesis and Evaluation of the Anti-Oxidant Capacity of Curcumin Glucuronides, the Major Curcumin Metabolites. Antioxidants. 2015; 4(4):750-767. https://doi.org/10.3390/antiox4040750

21. Bucak AK, Ozdemir C, Ulu S, Gonul Y, Aycicek A, Uysal M, et al. Investigation of Protective Role of Curcumin Against Paclitaxel-Induced Inner Ear Damage in Rats. Laryngoscope. 2015;125(5):1175-82. https://doi.org/10.1002/lary.25031

22. Yamaguchi T, Yoneyama M, Onaka Y, Imaizumi A, Ogita K, Preventive effect of curcumin and its highly bioavailable preparation on hearing loss induced by single or repeated exposure to noise: A comparative and mechanistic study. J Pharmacol Sci. 2017;134(4):225-33. https:// doi.org/10.1016/j.jphs.2017.07.003

23. Kavakli, HS, Koca C, Alici O, Antioxidant effects of curcumin in spinal cord injury in rats. Ulus Travma Acil Cerrahi Derg. 2011;17(1):14-8.

24. Aziza, SAH, Abdel-Aal SA, Mady HA, Chemopreventive effect of curcumin on oxidative stress, antioxidant status, DNA fragmentation and caspase-9 gene expression in 1,2-dimethylhydrazine-induced colon cancer in rats. Am J Biochem Mol Biol. 2014;4(1):22-34.

25. Meshkibaf MH, Maleknia M, Noroozi S, Effect of curcumin on gene expression and protein level of methionine sulfoxide reductase A (MSRA), SOD, CAT and GPx in Freund's adjuvant inflammation-induced male rats. J Inflamm Res. 2019;12:241-9. https://doi.org/10.2147/JIR. S212577

26. Zheng YY, Yu LS, Zhang YG, Ye GH, Yi JP, Effects of curcumin on malondialdehyde and cfos protein in hypoxia ischemia brain tissue in rats. Fa Yi Xue Za Zhi. 2009;25(1):6-8.

27. Soyalıç H, Gevrek F, Karaman S, Curcumin protects against acoustic trauma in the rat cochlea. Int J Pediatr Otorhinolaryngol. 2017;99:100-16. https://doi.org/10.1016/j. ijporl.2017.05.029 